\title{
HEXOSE PHOSPHATE LEVELS IN TESTES OF GALACTOSE-FED RATS
}

\author{
G. I. MOONSAMMY AND M. A. STEWART \\ Departments of Psychiatry and Pediatrics, Washington University Medical School, \\ St. Louis, Missouri U.S.A.
}

(Received 30th December 1970)

When rats are fed a diet with a high galactose content, the concentration of free myo-inositol in their testes is increased fourfold (Stewart, Sherman \& Harris, 1969). Because this compound is synthesized from glucose 6-phosphate (Eisenberg \& Bolden, 1965), we have looked for an effect of galactose feeding on the metabolism of hexose phosphates in testis.

Adult male Holtzman rats were fed either powdered chow or powdered chow mixed with galactose in a 3:2 ratio. Thirty-five animals were fed the galactose diet; groups of five rats were killed after 1,2,5 or 10 days on the diet. Three more groups of five rats each were fed the diet for 10 days and then killed 1,2 or 5 days after returning to a normal diet. One control animal was killed on each of the 7 days on which animals receiving the galactose diet were killed.

The animals were anaesthetized with intraperitoneal sodium pentobarbital and their testes were removed and frozen in liquid $\mathrm{N}_{2}$. The rats were then killed by decapitation and the liver and heart were removed and frozen immediately, together with the head. Tissues were stored at $-85^{\circ} \mathrm{C}$, then cleaned and weighed at $-18^{\circ} \mathrm{C}$. For hexose phosphate analysis, the tissues were extracted in methanol- $\mathrm{HCl}$ and $0.6 \mathrm{~m}-\mathrm{HClO}_{4}$ (King, Lowry, Passonneau \& Venson, 1967). Glucose 6-phosphate and fructose 6-phosphate were measured fluorometrically (Lowry, Passonneau, Hasselberger \& Schulz, 1964); galactitol and myo-inositol were measured by gas chromatography (Stewart, Rhee, Kurien \& Sherman, 1969).

Glucose 6-phosphate levels in the testes of galactose-fed rats increased immediately after the animals went on the diet, and showed a sustained fourfold increase from the 2 nd day onwards (Table 1 ). When the diet was stopped, the levels immediately returned to normal. The changes in fructose 6 -phosphate were roughly proportional to the changes in glucose 6-phosphate; the difficulty in measuring such low concentrations of fructose 6-phosphate directly probably explains the lack of exact correspondence.

Sherman, Goodwin \& Gunnell (1971) report that the $K_{m}$ for glucose 6phosphate in an inositol-synthesizing system derived from rat testis is $6.2 \mathrm{~mm}$

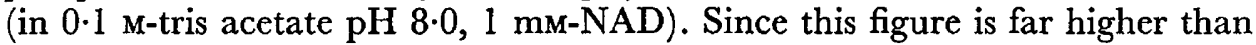
normal glucose 6-phosphate levels in testis, the alterations of hexose phosphate reported here would probably increase the rate of synthesis of inositol. This, in 
turn, provides a simple explanation for the higher level of inositol in the testes of galactose-fed rats.

We also measured the levels of glucose 6-phosphate in brain, heart and liver. There were no changes in brain, but in liver and heart the levels fell to about

TABLE 1

HEXOSE PHOSPHATE AND POLYOL LEVELS IN TESTES OF GALACTOSE-FED RATS

\begin{tabular}{|c|c|c|c|c|}
\hline & Glucose 6-P & Fructose 6-P & Galactitol & Myo-inositol \\
\hline Control & $42 \pm 4$ & $\begin{array}{c}\mu \mathrm{mol} / \mathrm{kg} \\
3.6 \pm 0.2\end{array}$ & et $w t \pm$ S.E.M. & $2120 \pm 130$ \\
\hline $\begin{array}{l}\text { On galactose diet } \\
1 \text { day } \\
2 \text { days } \\
5 \text { days } \\
10 \text { days }\end{array}$ & $\begin{array}{c}94 \pm 3 \\
157 \pm 12 \\
191 \pm 10 \\
152 \pm 15\end{array}$ & $\begin{array}{r}5.0 \pm 0.2 \\
8 \cdot 0 \pm 0.3 \\
18.7 \pm 0.2 \\
9.4 \pm 0.1\end{array}$ & $\begin{array}{l}4830 \pm 310 \\
7250 \pm 330 \\
7670 \pm 270 \\
7810 \pm 630\end{array}$ & $\begin{array}{r}6480 \pm 510 \\
9340 \pm 510 \\
8950 \pm 100 \\
10100 \pm 470\end{array}$ \\
\hline $\begin{array}{l}\text { On normal diet after } \\
10 \text { days on galactose diet } \\
1 \text { day } \\
2 \text { days } \\
5 \text { days }\end{array}$ & $\begin{array}{l}41 \pm 3 \\
58 \pm 6 \\
46 \pm 5\end{array}$ & & $\begin{array}{c}4800 \pm 600 \\
1160 \pm 180 \\
290 \pm 60\end{array}$ & $\begin{array}{l}7360 \pm 320 \\
4550 \pm 320 \\
2680 \pm 130\end{array}$ \\
\hline
\end{tabular}

$75 \%$ and $65 \%$ of the control values while the animals were on the galactose diet. The increase in glucose 6-phosphate may, therefore, reflect a metabolic effect peculiar to the testis.

This work was supported in part by U.S.P.H.S. grants NB-05463, MH07081 and $\mathrm{MH}-13,340$.

\section{REFERENCES}

Eisenberg, F. \& Bolden, A. H. (1965) D-Myo-inositol l-phosphate, an intermediate in the biosynthesis of inositol in the mammal. Biochem. biophys. Res. Commun. 21, 100.

King, L. J., Lowry, O. H., Passonneau, J. V. \& Venson, V. (1967) Effects of convulsants on energy reserves in the cerebral cortex. 7. Neurochem. 14, 599.

Lowry, O. H., Passonneau, J. V., Hasselberger, F. X. \& Schulz, D. W. (1964) Effect of ischaemia on known substrates and cofactors of the glycolytic pathway in brain. F. biol. Chem. 239, 18.

Sherman, W. R., Goodwin, S. L. \& Gunnel, K. D. (1971) Neo-inositol in mammalian tissues. Biochemistry, N.Y. (in press).

Stewart, M. A., Rhee, V., Kurien, M. M. \& Sherman, W. R. (1969) Gas chromatographic analysis of myo-inositol in microgram samples of brain. Biochim. biophys. Acta, 192, 361 .

Stewart, M. A., Sherman, W. R., Harris, J. T. (1969) Effects of galactose on levels of free myoinositol in rat tissues. Ann. N.Y. Acad. Sci. 165, 609. 